\title{
The Effect of Herringbone Technique on Students' Reading Comprehension through Narrative Text at MTs PAB 1 Helvetia, Medan
}

\author{
Rizky Vita Losi \\ Universitas Pembangunan Panca Budi \\ rizkyvitalosi@pancabudi.ac.id
}

\begin{abstract}
This research dealt with Herringbone technique which was proposed by Deegan (2006). The aim of this research was to know whether Herringbone technique was effective to be applied on students' reading comprehension through narrative text. The sample of this research was grade VIII-E students which consisted of 31 students at MTS PAB 1 Helvetia, Medan. The data of this research was students' reading comprehension score on pre-test and post-test. The data was analyzed by using Paired Sample TTest formula which was calculated by SPSS 2.2. From the data analysis, it was found that the T-Test value was higher than the T-Table value $(10,085>2,042)$. It showed that the alternative hypothesis $(\mathrm{Ha})$ was accepted and the null hypothesis (Ho) was rejected. It also showed that there was a significance effect after applying Herringbone technique on students' reading comprehension through narrative text at MTs $P A B 1$ Helvetia, Medan. To sum up, Herringbone technique is one of essential alternative for the success of reading comprehension for students.
\end{abstract}

Keywords: herringbone technique, students' reading comprehension, paired sample t-test formula

\section{INTRODUCTION}

In learning English, students are expected to master some language skills, namely: listening, speaking, reading and writing. It starts from listening which guides students to translate many English sentences from their ears and processes it on their brain to become understandable sentences. Then, speaking which allows students to say everything in their mind through sentences. Then, reading which helps students to get information from what they read. And the last is, writing which guides students to express their idea through writing text. Those skills will direct students not only to understand English, but also to use English as the communication.

Reading will be the main focus of this research. Reading is considered as the way to get much important information and knowledge. It involves active process to construct students' meaning from a text. This reading skill is needed by students in order to get much information and knowledge from everything the learn, especially English learning. Mastering the reading skill will help students a lot to get much more knowledge and to gain more English words.

Reading skill is still being the main issue which makes students are difficult to master it. Even reading skill gives many benefits, it seems that it isn't as easy as it is stated. Reading is not only about knowing what you read but also understanding the meaning conveyed on it. Once you know how to deal with it, it is easy to get the goal meaning from the text.

Zaccoletti (2020) states that to be success on education, students need to focus on many learning activities and reading comprehension is one of them. In education system, reading and comprehending texts are considered important to get a successful learning outcome and reading is about understanding the text comprehensively. Once the students are instructed to read a text, they will be asked to get the knowledge through the reading comprehension (Zaccoletti et al., 2020).

There are some problems found related to reading skill on students' learning English. The students admitted that they got it overwhelmed when they got a reading text, especially a full text such as 
narrative text. In narrative text, characters' actions, motives, problems, and personalities all contribute to the overall theme(s) of the story. The main idea often depends on the reader; if the reader has had similar experiences to the character, the reader is more likely to enjoy a richer, more fulfilling reading experience (Coe, 2004). Apparently, they stuck on many words which they even didn't know the whole meaning. It was because they were lack on English vocabulary as well. Moreover, the students couldn't get the main idea of the text, couldn't understand the meaning of the text and got it wrong to answer the questions given.

A significant effort is needed by the teacher to improve students' reading skill. The teacher can use various reading techniques to help the students improving their reading skill. One of many reading techniques is Herringbone technique. Deegan (2006) states that Herringbone technique is a strategy that develops reading comprehension of the main idea by plotting who, what, when, where, why, and how question on a visual diagram of a fish skeleton.

In line with the phenomena above, Tanjung (2014) conducted a research about Herringbone technique that focused on the recount text. She found that Herringbone technique recommended helping students in determining the important details in the recount text. For this reason, the researcher was interested to know the effect of Herringbone technique in different kind of text, which was narrative text in this case.

Based on the explanation above, a research was conducted in order to find the effect of Herringbone technique on students' reading comprehension through narrative text at MTs PAB 1 Helvetia, Medan.

\section{LITERATURE REVIEW}

According to Ahuja and Ahuja (2001), reading contributes to sensory and mental processes. The eye and mind works together while you're reading a text. The text is received by the eye in a message form and then the message is interpreted by the brain. This process needs students' understanding on the text meaning. They are expected to not only read the text but also understand the meaning.

Smith (2003) states that while you are reading a text, you construct understanding and concept within the text. It comes challenging when the students read unknown and uneasy text. The students need to be active and put much effort on reading. In addition, he also defines that reading comprehension refers to a process which is related to word recognition. The next step is, the students get the meaning from the text, even though it is an implicit meaning, they must able to react to this meaning.

Richard (2001) defines that reading comprehension refers to syntactic and semantic process which find information in printed text to rebuild in the reader's mind. According to Snow (2002), reading comprehension as the process of simultaneously extracting and constructing meaning through interaction and involvement with written language. From the theories presented above, it can be inferred that reading comprehension is an ability to understand a text by engaging the reader's experience and knowledge. The various comprehension comes from the readers' differences of experiences and knowledge background. Then, the comprehension process itself refers to what good readers do when reading a text.

According to Brown (2004), related to teaching and learning process, a teacher must provide a reading comprehension method for students which fulfills the reading comprehension goal. The way how the teacher present a text, develop the lesson and follow it up are three aspects that must be considered by the teacher. In this point, the teacher must provide a meaningful yet understandable explanation related to the text. Through this part, the students get a sense of purpose.

Deegan (2006) states that the Herringbone technique can be one of reading comprehension methods which can be offered to the students. It focuses on comprehension of the main idea by plotting the 
who, what, when, where, how, and why questions on a visual diagram of a fish skeleton. Using the answers to the why questions, the student writes the main idea across the backbone of the fish diagram.

Thaler (2008) adds that Herringbone technique provides of a short graphic organizer. If the teacher wants to help students comprehend the text through a paragraph or passage, this method is one of alternative to be given to the students. The students answer the questions listed in the fishbone graphic organizer. This leads to the synthesis of all the information in one newly created sentence, which becomes the main idea statement.

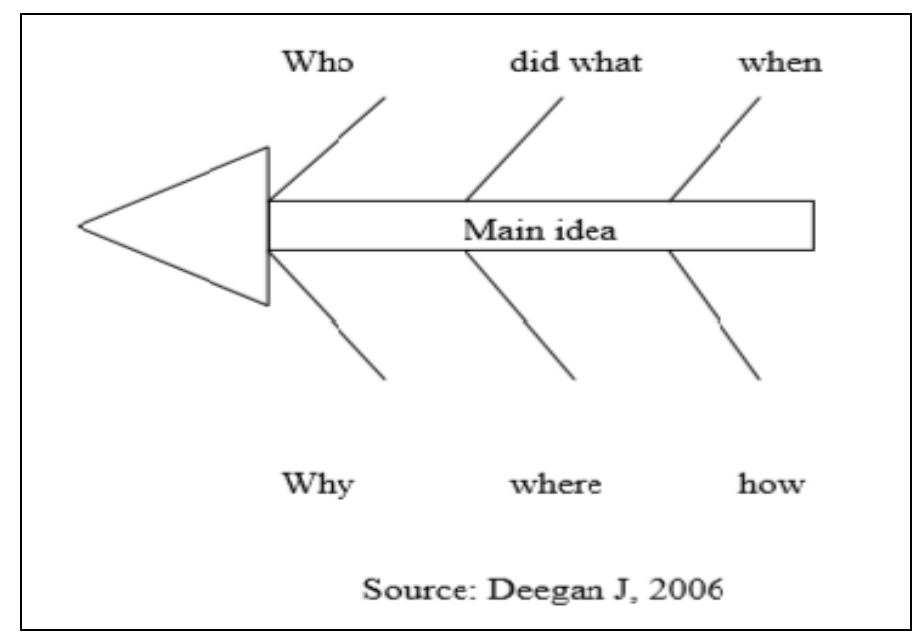

Figure 1. Herringbone Diagram

Deegan develops the Herringbone technique by using its name because it is as a representative to analyze the text through a fish skeleton. It consists of six questions that help students to arrange the details of the text systematically (Coe, 2004).

The Herringbone instructions are namely: 1. Processing focus: meaning, 2. Instructional phase: during and after reading, 3. Response mode emphasized: written response and oral discussion, 4. Strategy emphasized: elaboration, 5. Skill emphasized: literal comprehension, 6. Source of information: text based, 7. Type of instruction: implicit, 8. Type of cognitive processing: simultaneous, but it is written in a visual way (simultaneous) (Deegan, 2006).

The procedures of Herringbone technique are namely; 1 . The teacher chooses an appropriate text based on students' reading level, 2 . The teacher builds a visual diagram of the herringbone technique, 3. The teacher asks the student to answers the questions on the diagram. The students will focus on questions like: a. Who is the writer talking about? b. What did they do? c. When did they do it? d. Where did they do it? e. How did they do it? f. Why did they do it? 4. The student are asked to read the text and then find and write the answers on the diagram, 5. After the answers are written on the skeleton diagram, the teacher tells the students about each answer which suitable into each part in a main idea sentence, 6 . The students are asked to write a main idea, by using the answers they got from the herringbone diagram, 7 . The teacher duplicates sheets with the diagram, and the students complete the diagram on their own, 8. A story discussion is made by the diagram as a tool. During the discussion, the teacher and the students take their part to share and compare their answers and their reasons (Deegan, 2006).

While narrative text is a fictional text that helps to entertain the readers such as legends, myths, fairy tales, science fictions, roman novels and historical fiction. In general terms, simple past tense is used by narrative text in the way to tell a story. In line with this, Andersons (2002) states that a 
narrative text is a text that tells a story and, in doing so to entertains the audience.

The verb to narrate means to tell, to give all account of. Simply, making a narrative text is just write about someone's experience or whatever happens to her/him (Widyawati, 2003). In narrative, the incidents that make up the story are usually told in the order in which they would really happen. A narrative text can consist of actions that happens in a minute or years.

\section{METHOD}

The quantitative approach was used in this research by using pre-experimental design with one group pre-test and post-test design as well. Before giving a treatment, the students were administered a pre-test. Then, a treatment was given to the students and there was no test. At the last, the students were administered the post-test (Gay, 2006).

The application of Herringbone technique to teach reading comprehension was used as the independent variable and the increasing of students' score was used as dependent variable. The population of this research was the eighth-grade students of MTs PAB 1 Helvetia, Medan in academic year 2019/2020. There were 5 group classes as the population and the students of grade VIII-E were the sample of this research which consisted 31 students. The sample was chosen by the researcher as the consideration because grade VIII-E students had the lowest score on reading comprehension than other classes. The instrument of this research was reading comprehension test.

The technique of data analysis used was hypothesis testing by using Paired Sample T-Test formula which was calculated by SPSS 2.2. Through this hypothesis testing, it showed that Ho occurred if there was no effect of Herringbone technique to students' reading comprehension. While, Ha occurred if there was an effect of Herringbone technique to students' reading comprehension.

\section{FINDINGS AND DISCUSSIONS}

Here was the list of students' score on pre-test, it was shown clearly on Table 1.

Table 1. Students' Score on Pre-Test

\begin{tabular}{|c|l|c|}
\hline No. & Students' Initial Name & Pre-Test Score \\
\hline 1 & AS & 50 \\
\hline 2 & ARN & 60 \\
\hline 3 & AR & 80 \\
\hline 4 & DC & 20 \\
\hline 5 & DAP & 30 \\
\hline 6 & DAE & 40 \\
\hline 7 & DIA & 80 \\
\hline 8 & FHP & 30 \\
\hline 9 & IR & 50 \\
\hline 10 & IP & 60 \\
\hline 11 & MA & 70 \\
\hline 12 & MSD & 10 \\
\hline 13 & MR & 50 \\
\hline 14 & MDZ & 60 \\
\hline 15 & MH & 90 \\
\hline 16 & MZ & 70 \\
\hline 17 & NP & 10 \\
\hline 18 & NRA & 20 \\
\hline 19 & NA & 10 \\
\hline 20 & NAN & 60 \\
\hline 21 & NAP & 40 \\
\hline & & \\
\hline
\end{tabular}




\begin{tabular}{|c|l|c|}
\hline No. & Students' Initial Name & Pre-Test Score \\
\hline 22 & NF & 80 \\
\hline 23 & RDH & 50 \\
\hline 24 & RFL & 50 \\
\hline 25 & SA & 60 \\
\hline 26 & SAH & 90 \\
\hline 27 & SYA & 40 \\
\hline 28 & SAB & 60 \\
\hline 29 & UK & 70 \\
\hline 30 & YR & 40 \\
\hline 31 & ASAS & 60 \\
\hline
\end{tabular}

Then, here was the list of students' score on post-test, it was shown clearly on Table 2 .

Table 2. Students' Score on Post-Test

\begin{tabular}{|c|c|c|}
\hline No. & Students' Initial Name & Post-Test Score \\
\hline 1 & AS & 80 \\
\hline 2 & ARN & 90 \\
\hline 3 & AR & 90 \\
\hline 4 & $\mathrm{DC}$ & 70 \\
\hline 5 & DAP & 70 \\
\hline 6 & DAE & 80 \\
\hline 7 & DIA & 100 \\
\hline 8 & FHP & 70 \\
\hline 9 & IR & 80 \\
\hline 10 & IP & 80 \\
\hline 11 & MA & 90 \\
\hline 12 & MSD & 70 \\
\hline 13 & MR & 80 \\
\hline 14 & MDZ & 90 \\
\hline 15 & $\mathrm{MH}$ & 100 \\
\hline 16 & $\mathrm{MZ}$ & 90 \\
\hline 17 & NP & 80 \\
\hline 18 & NRA & 80 \\
\hline 19 & NA & 80 \\
\hline 20 & NAN & 80 \\
\hline 21 & NAP & 70 \\
\hline 22 & NF & 90 \\
\hline 23 & $\mathrm{RDH}$ & 80 \\
\hline 24 & RFL & 80 \\
\hline 25 & $\mathrm{SA}$ & 80 \\
\hline 26 & SAH & 100 \\
\hline 27 & SYA & 70 \\
\hline 28 & SAB & 80 \\
\hline 29 & UK & 80 \\
\hline 30 & YR & 80 \\
\hline 31 & ASAS & 80 \\
\hline
\end{tabular}

Having calculated the students' pre-test and post-test score, it could be seen on Table 2 below that 
the mean of students' pre-test score was 51,29 and the mean of students' post-test score was 81,94 . It showed that pre-test score was lower than post-test score $(51,29<81,94)$ then it meant that there was an effect on students' reading comprehension score.

Table 3. Paired Samples Statistics

\begin{tabular}{|ll|r|c|c|c|}
\hline & & Mean & N & Std. Deviation & Std. Error Mean \\
\hline Pair 1 & Pre Test & 51,29 & 31 & 22,766 & 4,089 \\
& Post Test & 81,94 & 31 & 8,725 & 1,567 \\
\hline
\end{tabular}

Based on correlation test result on Table 3 above, it was found that correlation coefficient was 0,776 with significance value was 0,00 . Because the significance value was $0,00<0,05=\alpha$ and it could be stated that there was a correlation between pre-test variable and post-test variable.

Table 4. Paired Samples Correlations

\begin{tabular}{|ll|c|c|c|}
\hline & $\mathrm{N}$ & Correlation & Sig. \\
\hline Pair 1 & Pre Test \& Post Test & 31 &, 776 &, 000 \\
\hline
\end{tabular}

Based on Table 4 above, it was found that t-test value was $-10,085$. T-test value was negative because the mean of post-test score was higher than the mean of pre-test score. In this case, negative ttest value could be changed positive so t-test value became 10,085. It was also found that t-table was 2,04227 . Thus, t-test value was higher than t-table $(10,085>2,042)$ so it could be concluded that Ha was accepted and Ho was rejected.

Table 5. Paired Samples Test

\begin{tabular}{|c|c|c|c|c|c|c|c|c|}
\hline & \multicolumn{5}{|c|}{ Paired Differences } & \multirow{3}{*}{$\mathrm{t}$} & \multirow{3}{*}{$\mathrm{df}$} & \multirow{3}{*}{ Sig. (2-tailed) } \\
\hline & \multirow[t]{2}{*}{ Mean } & \multirow[t]{2}{*}{$\begin{array}{c}\text { Std. } \\
\text { Deviation }\end{array}$} & \multirow[t]{2}{*}{$\begin{array}{l}\text { Std. Error } \\
\text { Mean }\end{array}$} & \multicolumn{2}{|c|}{$\begin{array}{c}95 \% \text { Confidence } \\
\text { Interval of the } \\
\text { Difference }\end{array}$} & & & \\
\hline & & & & Lower & Upper & & & \\
\hline $\begin{array}{cc}\text { Pair } & \text { Pre Test } \\
1 & \text { - Post } \\
& \text { Test }\end{array}$ & $-30,645$ & 16,919 & 3,039 & $-36,851$ & $-24,439$ & $-10,085$ & 30 &, 000 \\
\hline
\end{tabular}

Moreover, having calculated all scores by using T-test formula, it was found that the result of T-test value on students' reading comprehension (before and after implementing the treatment) indicated that the $\mathrm{T}$-test value was higher than the $\mathrm{T}$-table value $(10,085>2,042)$. This finding used to determine the hypothesis that occurred in this research as it was stated that the null hypothesis (Ho) is rejected if T-table value was greater than T-test value, and the alternative hypothesis (Ha) was accepted if T-test value was greater than T-table value. It can be seen on Table 5. It was found that there was a significance effect after applying Herringbone technique on students' reading comprehension through narrative text at MTs PAB 1 Helvetia, Medan.

To sum the findings up, based on the data represented above it can be stated that the use of herringbone technique in teaching reading comprehension made the students understand more the narrative text. The diagram also helped the students easier to answer questions and the main idea related to the text properly because they could comprehend detail information, main idea and vocabulary. 


\section{CONCLUSION}

From the data analysis, it could be concluded that Herringbone technique was one of successful technique to apply on students' reading comprehension. It had significantly given the effect on students' reading comprehension score. It could be seen from students' post-test score which showed the improvement from students' pre-test score.

It could be seen from hypothesis testing as well that the alternative hypothesis (Ha) was accepted. At the end, Herringbone technique could significantly improve students' reading comprehension at MTs PAB 1 Helvetia, Medan.

\section{REFERENCES}

Ahuja, G. C \& Ahuja, P. (2001). How to increase reading speed. Sterling Publishers.

Anderson, M. \& Anderson, K. (2002). Text types in english 3. MacMillan Education Australia.

Brown, H. D. (2004). Teaching by principles. Longman.

Coe, Z. V. \& Glass, C. (2004). Herringbone Pattern.

http://www.marcoislandchartermiddleschool.org/Herringbone\%20Pattern.pdf

Deegan J. (2006). Herringbone technique translation journal, Teacher web. http://www.teacherweb.com/HerringboneTechnique.doc

Gay, L. R., E., Millis \& Arasian. P. (2006). Educational research: competencies for analysis and application.। Prentice Hall.

Richards, J. C., \& Renandya, W. A. (Eds.). (2002). Methodology in language teaching: an anthology of current practice. Cambridge University Press.

Snow, C. (2002). Reading for understanding. Towards an R\&D Program in Reading Comprehension. RAND Corporation.

Tanjung, F. \& Putra, A. D. (2014). Improving reading skill by using herringbone technique in recount text for senior high school. Ejurnal.

http://ejurnal.bunghatta.ac.id/index.php?journal=JFKIP\&page=article\&op=view\&path\%5B\%5 $\underline{\mathrm{D}=3524 . p d f}$

Thaler, E. (2008). Teaching english literature. Verlag Ferdinand Schoningh.

Widyawati, S. (2003). Pembelajaran dan evaluasi writing. Departemen Pendidikan dan Kebudayaan Direktorat Jenderal Pendidikan Tinggi.

Zaccoletti, S., Altoè, G., \& Mason, L. (2020). Enjoyment, anxiety and boredom, and their control-value antecedents as predictors of reading comprehension. Learning and Individual Differences, 79(February 2019), 101869. https://doi.org/10.1016/j.lindif.2020.101869 


\section{Appendix: Reading Comprehension Test}

\section{The Goose that Laid Golden Eggs}

(Taken from http://englishjuniorhighschool.blogspot.com/2012/05/goose-that-laid-golden-eggs.html)

Once upon a time, there lived a happy family in a village. A man and his wife lived happily on a little farm, tending their flock of geese and selling their eggs at the market. They were not rich, but they were happy with their life together.

Then one day a new goose flew in among their flock. The couple was surprised to find a shiny golden egg in her nest. Each and every day after that, the goose laid another egg of solid gold! The couple was soon richer than they had ever dreamed of, but they were not happy. They grew impatient with only one golden egg a day. The farmer said to his wife, "Our goose must be full of gold. Why should we wait to have more eggs?"

"If we cut her open," his wife agreed, "we can get all the eggs at once." So they killed the goose! They were very surprised to find that it was just like any other goose inside. Even worse, there would never be any more golden eggs!

\section{Instructions:}

A. Read the narrative text above then answer these questions on the template by using Herringbone technique!

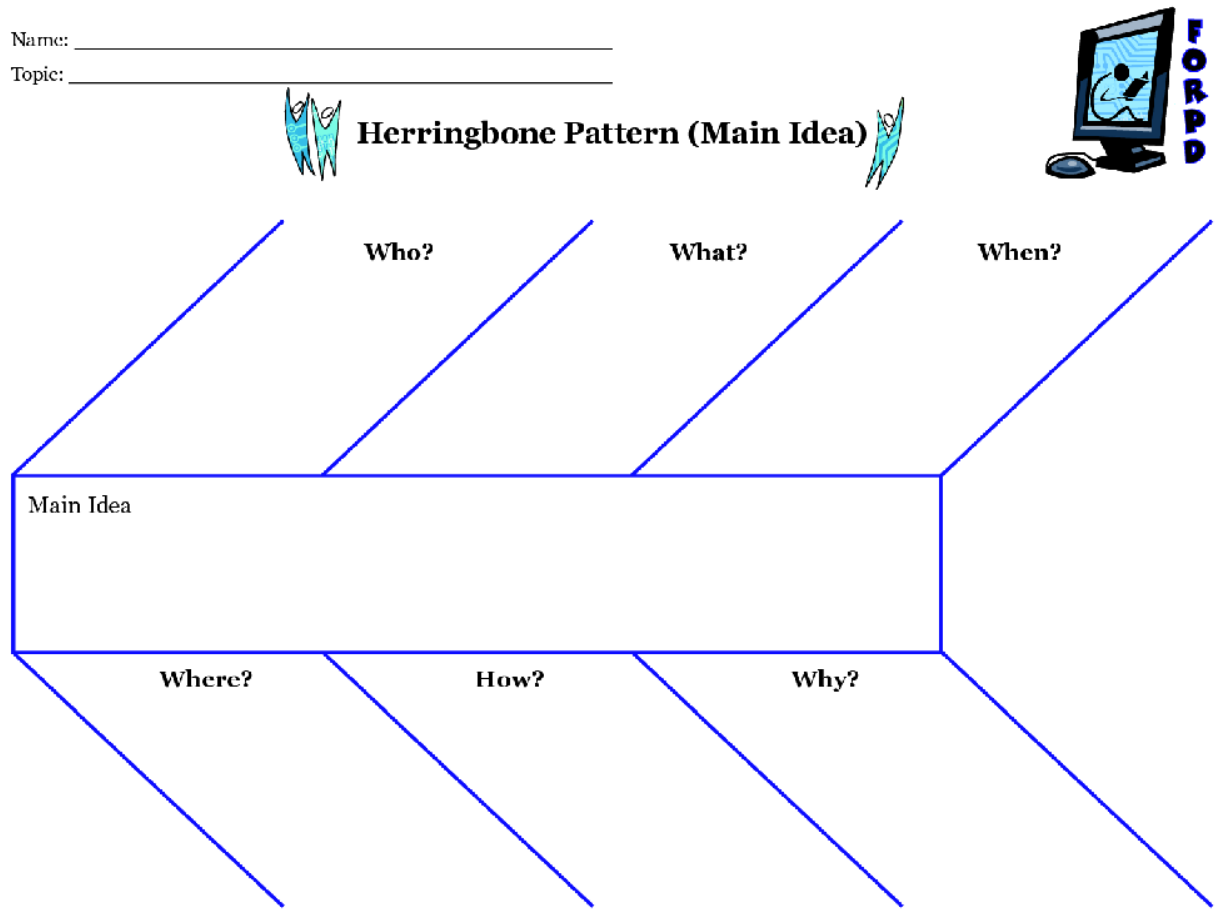

(Taken from https://i.pinimg.com/originals/2a/89/52/2a89523018a220de89c60db1af787a3c.png)

\section{B. Answer these questions below!}

8. What do you think about the man's character?

9. What do you think about his wife's character?

10 . What is the message of the story? 